\title{
Market Chain for Cereal and Pulse Crops in North Shewa Zone of Oromia Regional State, Ethiopia
}

\author{
Teferi Girma Bekele (Corresponding author) \\ Debre Berhan University, Debre Berhan, Ethiopia \\ E-mail: Teferigr@gmail.com
}

\author{
Getamesay Bekele Meshesha (PhD) \\ Debre Berhan University, Faculty of Business and Economics \\ Department of Economics, Debre Berhan, Ethiopia \\ E-mail: getamesaybkk@gmail.com
}

Received: August 1, 2017 Accepted: September 5, 2017

doi:10.5296/ber.v7i2.11622 URL: https://doi.org/10.5296/ber.v7i2.11622

\begin{abstract}
This study provides empirical analysis on the market chain for cereal and pulse crops by measuring profit of rural farming households in North Shewa Zone of Oromia Regional State, (Ethiopia). Marketing problem of agricultural products happens because of internal and external problem of the farmer. The purpose of this study is to provide empirical evidence on the market chain in the area. Multistage sampling technique was used to select 393 sample farming households. Additionally, 20 merchants, 10 government employees and 1 Salale Union worker respondents were included in the study. The mixed research method employed to make the result more fruitful. Some descriptive analysis and Logistic regression were used for the econometric part. Even if some independent variables are insignificant, result of the model shows that market chain positively affects the profitability of the farmer. The areas with market chain for both agricultural input and agricultural product have relatively high profits. Farmers who use agricultural inputs from market cooperatives and sell their crops to the cooperatives are highly productive and more profitable. These results confirm that market chain contributes directly for improving the profitability of rural farming households, and hence scaling up the trading among farmers. Minimizing marketing problem and increasing awareness, financial access and road access for farmer by concerned local government institutions and nongovernmental organizations were recommended to improve farmers' profitability.
\end{abstract}


Keywords: Market chain, Logistic model, cereal and Pulse, Profit, North Shewa Zone

\section{Introduction}

Agriculture is the dominant economic activity in developing countries that contributes about $20 \%$ of the GDP, $60 \%$ of employment and $80 \%$ of the export. Many developing countries have the agriculture development led industrialization policy. When we compare agricultural product of less developed countries with developed countries, the later exceeds nine times the product of the former. Agricultural product in many developing countries, are mixed family agriculture that means, many products used for consumption when the left is sold (World Bank, 2004). So, different theoretical literatures and practical works indicate having efficient domestic agricultural commodity marketing system plays a major role in accelerating the growth and development of the agriculture sector. Besides, it makes the participants in the market chain such as producers, traders and consumers' beneficiary as per their role and efforts exerted in the system (Mohammed, et, al., 2015).

In less developed countries, farmers face the reality of an incomplete transition and inefficient supplier of agricultural products. This inefficient and low supply of agricultural product creates the new driver of consumer demand, as mediated by the large scale downstream of buyers and retailers. There is the emergence of a phenomenon of market concentration, in the input supply industry, agro-processing and in the retail industry segments while the agriculture market is fragmented. There is also the risk of supermarket chains progressively "crowding out" the informal agricultural markets that need to be acknowledged and mitigated. The processes of organizational and institutional restructuring need to accompany this transition constitute a significant challenge for policy makers and market operators (Christy, 2009).

In Africa, per capita supply of fresh products declined from 1970 to 1999 by average of $0.3 \%$ per year (USAID, 2005). This decline has been driven by falling real incomes, but also by increasingly inadequate production and marketing systems that limit yield growth at the farm level and increase marketing costs throughout in supply chain. Undeveloped and unorganized marketing system have several economic problems, such as it may lead an inflationary and disinflationary environment, low return for producer, loss of foreign currency by exporting less of the commodity low capital formation and low investment of farmers. (Muhammed et al., 2015).

Besides, the retailer, collector merchant cheat farmers by measurement materials like unpropertasa, jog, modern scale because from small market to large market or/and in the same market traditional as well as modern scale measurement materials are undefined in some area of Ethiopia (Muhammed 2011). The ZFED (2014) office showed that the farmer profitability is not as productivity of the farmer due to no standard measurement material in the market.

Even, farmers' cooperatives are established and they have no strong relation with consumers' cooperatives, agro processing micro and small scale enterprise and agro processing industries. The other problem is seasonal market difficulties, this is during harvesting and collection 
time farmers' expense is too many. Taxation, recreation, wedding and other ceremony are main challenges of the farmers after harvesting and collection period. Farmers have the problem of market, financial access, road access, external and internal problem of awareness of marketing and properly store their products. When we look at the cost of input like improved seeds, Fertilizers, Pesticide, Insecticide supply chain with farmer are not enough, these increase cost to the farmers. Those problems are adversely affecting the profitability of the farmers. These all farmers go toward unexpected low price sell for cheater merchants, farmers do not get bargaining power for their products and all problems affect negatively the price of agricultural products, and it results the profit of farmers decline.

Generally, North Shewa Zone has large products of cereal and pulse crops. In the areas cereal like teff, wheat, burley, maize, sorghum, millet and pulse different types of Beas, pea, lentil crops are very dominant product of the farmers. Annually, about 7,967,002 quintals of cereal and pulse are produced in the area; out of these, 5,469,750 quintals were pulse and 1,801,903 quintals were cereals. In addition to this farmers in the area are very known by dairy production and livestock breeding (ZFED, 2014). This study aimed to identify the main factors affect the market chain of cereal and pulse crops and to investigate factors that affect profitability of the farmers in the area by answering the following questions.

a. What are the main factors that affect the market chain of cereal and pulse crops in the zone?

b. What are the factors that affect profitability of the farmer in the area?

\section{Literature Review}

Market chain defined as "The numerous links that connect all the actors and transactions involved in the movement of agricultural goods from the farm to the consumer." Supporting these activities are services that enable the chain to operate. Agricultural goods and products flow up to mediators and money flows down farmers in the chain. The efficiency of the market chain is generally a factor of how well information flows among these actors. Given the many challenges of the marketplace, it is vital to suggest that a practical starting point in developing a marketing strategy is to assist chain actors to visualize their market chain from beginning to end. Market chains operate most competitively when they are supported by dedicated business organizations, both formal and informal, which participate in enabling produce to flow from the farm gate to the final consumer (Lundy et al., 2004).

\subsection{Theoretical Literature}

Market: market is a place where price-making force drives and exchanges of title tend to be convoyed by the actual movement of the goods exaggerated (Alemu, 2010). The concept of exchange and interactions lead to the concept of market. It is the collection of the potential sellers and buyers of a product (Mohammed, 2011). A market can be described as simple arrangements to facilitate exchange of one thing for another. The most observable features of a market are its pricing and exchange processes and it is more than a physical place. 


\subsection{Market Chain Vs Value Chain}

The terms market chain, supply chain, production chain, and value chain are often looks similar but they are different terms (Table 1). Simply, the terms market chain, supply chain and production chain are synonymously used to describe all participants involved in an economic activity which uses inputs and services to enable a product to be made and delivered to a final consumer. A value chain is a strategic network between a numbers of self-determining business organizations. According to Hobbs, et, al., (2000), a value chain is differentiated from a production/supply chain because participants in the value chain have a long-term strategic vision, disposed to work together, oriented by demand and not by supply, shared commitment to control product quality and have a high level of confidence in one another that allows greater security in business and facilitates the development of common goals and objectives.

\subsection{Profit Maximization of Firm}

According to Mankiw, 1998, Profit is a function of revenue and cost that deducting cost from revenue that is Profit $=$ Revenue - Labor Costs - Capital Costs

$$
\pi=p y-w l-r k
$$

To see how profit depends on the factors of production, we use the production function $Y=F(K$, $L)$ to substitute for $Y$ to obtain

$$
\text { Profit }=p f(k, l)-w l-r k
$$

This equation shows that profit depends on the product price $P$, the factor prices

$W$ and $R$, and the factor quantities $L$ and $K$. The competitive firm takes the product price and the factor prices as given and chooses the amounts of labor and capital that maximize profit (Mankiw, 1998).

Similarly, Varian also explains profitability of firm as follows; the profit is the problem of a firm that takes prices as given in both its output and its factor markets. Let $\mathrm{p}$ be a vector of prices for inputs and outputs of the firm. The profit maximization problem of the firm can be stated as

$$
\pi(p)=\max (p y)
$$

Such that $\mathrm{y}$ is in $\mathrm{Y}$.

Since outputs are measured as positive numbers and inputs are measured as negative numbers, the objective function for this problem is profits: revenues minus costs. The function $\pi(p)$ which gives us the maximum profits asa function of the prices, is called the profit function of 
the firm(Varian, 1992).

\subsection{Empirical Literature}

There are few empirical studies concerning the market chain in different types of crops and others productions. So, different scholars looked advantage of market chain for many market chain actors. There are also a few studies that are discussed the transaction cost with in agricultural inputs. Among these:

Riohm et al., 2009, ILO, 2009 and Kirsten et al., 2009 journals and book respectively said advantage of value chain economically, if millers were to operate the whole industry without out growers, there would be no debate about the sharing of the proceeds, and essentially each stage in the value chain would be treated as a cost center.

Zekarias et al., 2012, studies market structure showed that wholesalers, assemblers and producers are the main players involved in the market chain of coffee in the study area. The concentration Wholesalers' in local coffee sales index (40\% for Gera and 29.64\% for Shebe) revealed that there is a risk of Oligopoly in the market structure of coffee especially in Gera area. The market conduct investigation exposed that price setting mechanism is largely determined by the benevolence of buyers and the existing market force in the producers and exporters market respectively. The largest profit margin (50.98\% margin is taken by exporters in the coffee market chain.

Bellu, 2013, work found that Part of the paddy rice (10\%) is lost after harvesting due to poor management of post-harvest storage, while the remaining rice is sold to steamers. In order to reduce the losses, better storing facilities at farm level can be introduced. The value chain for farmer decreases the losses to $5 \%$ of the crop production, enabling the farmers to gain higher profits from the total output sold.

Sintayehu et al., (2013) studied on concept of value chain as the communication of market requirements by traders, feedlot operators, retailers and exporters is currently restricted due to the availability of substantial profits from moving animals between locations and over time. This is due to poorly integrated markets and highly seasonal sales practices by producers. Government action is justified in the promotion of market information: through collection, analysis and dissemination. Substantial experience suggests that sustainability of such activities is difficult, so low-cost options need to be identified and examined, perhaps focusing on dissemination via co-operatives that are currently operating more as traders than as service providers to members.

Getachew et al, 2014, conducted study on the market chain analysis and development on vegetables with different factors that affect the value chain and profitability of farmers are seen as follows. Improving production side of the value chain by enhancing/establishing regulatory system/bodies to regulate the quality for locally produced improved seed varieties and imported inputs, chemicals, and enhancing product quality and safety including those for export market, strengthening formal seed business, irrigation extension, provision of tax incentives for importing quality pump, developing national data base on vegetables cropping calendar and product diversifications so as to minimize market saturation. Besides, expanding 
market infrastructure and facilitations (standards/grades, access to finance), timely delivery of market information and promotion of affordable storage system for the producers to increase the shelf life of their products, creation of market linkages, building capacities of producer associations, farmers and relevant government institutions should be given due attention for value chain development.

Mekbib et al, 2014, study explained that the benefit for rural farmers of higher output prices depends on the marketable surplus they produce and take to nearby grain markets. Coupled with the limited surplus output, high transaction costs and inadequate market information limit the commercialization level of rural farmers. Although there exists variation across different regions of the country, commercialization of smallholder farmers is generally limited. About $20 \%$ of smallholder grain production is marketed whereas above $60 \%$ is used for home consumption. The remaining is set aside for seed or used as animal feed and for in-kind-payments.

The market focus study showed that in Asaita, the goat market composition was a loose oligopoly with a concentration ratio of 44.81, subjugated by a small number of formal and informal male traders and butchers. This analysis of market margins and performance revealed that, because medium-scale traders are well connected to markets offering good prices, most producers are obliged to sell their goats through the channels they control. The study analyzed that if the producers organise into cooperatives, they could gain greater collective control over the supply of goats to traders and markets (Gebremariam, et al., 2015).

From ongoing discussion there are few studies on the market chain analysis in Ethiopia. While studying the market chain analysis there is a need to check the profit maximization of the farmer with market chain, impact to unobserved selection bias using maximum likelihood procedure (based on the nature of the outcome variable). Here the study tries to use appropriate econometrics model like logistic model for binary dependent variable response. This is because of many house hold have no interest to talk about their income and profit. Instead of asking households how many birr did you get from cereal and pulse crops production profit per year? Are profitable or not? Is more interesting question to get fruit full data from farmer house hold. Since this outcome is binary response, logistic regression model is vitally proper model.

\section{Methodology and Data Description}

\subsection{Research Design}

Research design is the blueprint for fulfilling research objectives and answering research questions (Creswell, 2009).In other words, it is a master plan specifying the methods and procedures for collecting and analyzing the needed information. It ensures that the study would be relevant to the problem and that it uses economical procedures. From the types of research design this research was employed descriptive and empirical research.

Moreover, the study utilized cross-sectional data in the sense that all relevant data were collected at a single point in time. The reason for preferring a cross-sectional study is because of getting organized long year data was difficult in the area. Obtaining information from a 
cross-section of a population at a single point in time is a reasonable strategy for pursuing many descriptive researches (Janet et al., 2006).

\subsection{Study Area}

North Shewa is one of the zones of Oromia Regional State. It is surrounded by Amhara National Regional State and three Oromia zones, which is North shewa of Amhara National Regional State in the North and East direction, in the Western, West Shewa zone of Oromia regional state, Oromia special zone surrounding Finfinne in the south, and in the South East Shewa. Astronomically, the Zone lies between $8^{0} 55^{\prime} \mathrm{N}$ and $10^{\circ} 23^{\prime} \mathrm{N}$ latitude and $37^{0} 56^{\prime} \mathrm{E}$ and $39^{0} 32^{\prime}$ E longitude (ZFED 2014).According to 2007 Population and housing census projection result and their progression, the total population of the zone in 2014 was 1,523,743 from these, rural population were 1,466,103 (males 730,266 \& females 735,837) while population of the study is 183,624 rural farmers of selected woredas of the Zone (ZFED 2014).

The settlement of population density varies from districts to districts. Population settlement in the zone is characterized by generally uneven distributions, in some areas there are densely and some areasare scatter populated. More than half of the districts in the zone have greater than the densities of the zone which is 142 person $/ \mathrm{km}^{2}$ in 2013 and 146 person $/ \mathrm{Km}^{2}$ in 2014 . The highest crude densities in rural districts in 2013 is in Debere Libanos with the densities of 263 person $/ \mathrm{Km}^{2}$ followed by Hidebu Abote 190 person $/ \mathrm{Km}^{2}$, GirarJarso181 person $/ \mathrm{Km}^{2}$ and Degem,YayaGulale157 person $/ \mathrm{Km}^{2}$ while in 2014 the densities of the population increased to $271,195,161$ and 186 persons $/ \mathrm{Km}^{2}$ the mentioned districts respectively in the zone. The sparsely populated in selected woreda of the zone is Dera 123 person $/ \mathrm{km}^{2}$ in 2013 . The settlement is found here and there in the zone, with more concentration in and along the lower slopes of the high lands and plateaus (ZFED, 2014).

North Shewa zone has the total area of $8,989.8 \mathrm{~km}^{2}$ with, diverse climate, which results great varieties of fauna and flora, possess large area of farming land, possess high productivity of dairy farming due to conductive climate, and has a great variety of natural resource like wildlife, minerals (ZFED, 2014).

\subsection{Methods of Data Collection}

To this study the data were collected from primary source as well as secondary sources.

\subsubsection{Primary Source}

In order to realize the final target of the study, researcher uses well-designed questionnaires as the best instrument. This was done by distributing open ended questionnaires (semi structured questionnaires), interviewing focal group from farmers and interviewing key informants from government workers, merchant and nongovernment workers participating in the areas. Semi structured questionnaires are necessary for more explanation of some wanted data. 


\subsubsection{Secondary Source}

Secondary data were gathered from national and regional websites, zonal and woredas' reports, office manuals, and policy papers to provide additional information where appropriate. Besides, variety of books, published and/or unpublished government documents, websites, reports and newsletters reviewed to make the study fruitful.

\subsubsection{Sample Size Estimation and Sampling Method}

Multistage random sampling technique used to get information from different sizes of the population specially land plough farmers. This technique is preferable because of population in the study area of research was gone to proceeded is homogeneous population with economic activity, particularly land plough, animal breed and bee keeping. According to Janet (2006), this step increases the probability that the final sample represents in terms of the multistage clustering is necessary. North Shewa Zone has 13 woredas and 267 rural kebeles (ZFED, 2014). From 13 woredas of the Zone 5 woredas were selected, from these woredas depending on their area 30 sampled kebeles were selected. Proportionally from the kebeles 120 villages and after pass through these three stages finally, 406 farmers household were selected as sample units by random sampling. Out of the 406 household 393 respondents took the answer.

The correct sample size in a study is dependent on the nature of the population and the purpose of the study. The sample size selected here is considered as representative of small households who participate in farming specially producer of cereal and pulse crops in the area. To determine sample size the study used sample size formula (Dawson2009).

Where $n=$ sample size

$\mathrm{p}=$ probability of farmers profitable

$\mathrm{q}=$ probability of farmers not profitable

$\mathrm{z}=$ standardized normal value

$\alpha=$ level of significance

$$
n=\frac{\mathrm{z} 2 * p * q}{\alpha 2}
$$

Based on ZFD 2014 report, the researcher estimated that only $40 \%$ of the farmers in the area are profitable and the left $60 \%$ farmers are not profitable. The study set $\mathrm{z}=$ at $95 \%$ and its standardized normal value is $1.96, P=0.4$ and $q=0.6 \quad \alpha=0.05$

By using the above formula, minimum sample sizes of 369 is calculated. So, from the total population, the researcher collected only 406 that are expected to represent wide population by considering $10 \%$ i.e. 37 for non-respondent households. 


\subsection{Data Analysis}

This is further transformation of the processed data to look for patterns and relationship between and/or among data groups by using descriptive and inferential analysis. Specifically, descriptive statistics (percentage and standard deviation) standard deviation and inferential statistics (correlation and regression) were taken for this study. And also, profit is dependent variable and factors affecting profit like market price of the crops, quantity, costs of inputs, awareness of the farmers, road access to the house holds dweller, market information, fixed cost of households, family size, interest (cost of capita) are independent variables. Price disturbance like measurement material, financial access and taxation period are analyzed in the study. Since profit is a difference of Revenue and cost, can put

$$
\Pi=\mathrm{TR}-\mathrm{TC}+u
$$

Where $\Pi=$ Profit of the firm

$$
\mathrm{TC}=\text { total cost }
$$

$\mathrm{TR}=$ Total Revenue

$u=$ error terms

\subsubsection{Descriptive analysis}

Descriptive analysis uses to reduce the data into a summary format percentage and standard deviation. The reason for using descriptive statistics is to compare the different factors. Besides, the interview questions are analyzed using descriptive narrations through sequential triangulation strategy. Triangulation is often used to indicate that two (or more) methods are used in a study in order to check the results of one and the same subject. Triangulation is a powerful technique that facilitates validation of data through cross verification from two or more sources. In particular, it refers to the application and combination of several research methods in the study of the same phenomenon (Creswell, 2009).

\subsubsection{Model Specification}

The study model is specified as

$$
\mathrm{Y}_{\mathrm{i}}=\mathrm{F}\left(\mathrm{X}_{1}, \mathrm{X}_{2} \quad \ldots \quad \mathrm{X}_{9}\right)
$$

In this study $\mathrm{Yi}=$ profit from cereal and pulse crops

$\mathrm{Xi}=$ set of independent variables

\subsection{Diagnosis Tests}

Before fitting important variables into the multiple regression models, it is necessary to test multi-co-linearity problem among continuous variables and check associations among discrete variables, which seriously affect the parameter estimates. Not only this, but also need to test Ramsey regression specification error for omitted variable, information criteria test and manage some outlier by using semi logline model. According to Gujarati, 2003, multi-co-linearity refers to a situation where it becomes difficult to identify the separate effect of independent variables on the dependent variable because existing strong relationship among them. In other words, multi-co-linearity is a situation where explanatory variables are 
highly correlated. There are two measures that are often suggested to test the existence of multi-co-linearity. These are Variance Inflation Factor (VIF) for association among the continuous explanatory variables and Contingency Coefficients (CC) for dummy or discrete variables.

Another problem is hetroschedasticity: According to Gujarat, 2003, heteroscedasticity, that is, diverse variances between residual terms. To detect heteroscedasticity problem the study uses Breusch-Pagan / Cook-Weisberg test. The result shows that even variance is constant at $\mathrm{H}_{0}$ Prob $>\mathrm{chi}^{2}=0.000$ tells us reject $\mathrm{H}_{0}$, that means there is problem of heteroscedasticity. To minimize this problem the researcher regressed by robust Logistic regression.

\subsection{Model Estimation}

After selecting logistic model for the analysis, the dependent variable is assigned a value of 1 or 0 , representing profitable or not profitable, respectively. Since the method of OLS does not make any assumptions about the probabilistic nature of the disturbance term vi in logistic regression, the parameters of the model were estimated using the maximum likelihood (ML) method (Gujarati 2003). Due to the non-linearity of the logistic regression model, an iterative algorithm is necessary for parameter estimation. The ML method is a very general method of estimation that is applicable to a large variety of problems. ML method involves choosing the values of the parameters that maximize the likelihood function.

Logistic model estimation: Logistic regression is a nonlinear regression model that forces the output (predicted values) to be either 0 or 1 . Logistic models estimate the probability of dependent variable to be $1(\mathrm{Y}=1)$. This is the probability that some event happens. Logistic model express as,

$$
p=\Lambda\left(\mathbf{x}^{\prime} \boldsymbol{\beta}\right)=\frac{e^{\mathbf{x}^{\prime} \boldsymbol{\beta}}}{1+e^{\mathbf{x}^{\prime} \beta}}
$$

(Cameron, et, al., 2005)

$\mathrm{P}=$ probability

$\mathrm{X}=$ predicted dependent variable

$\mathrm{B}=$ coefficient of the independent variable

e =base of natural logarithm.

\subsection{Data Presentation and Analysis}

\subsubsection{Socio-Demographic Characteristics of Farming Households}

Socio-demographic characteristics present the profile of the sample respondents with consider to their sex and education level. There are only 47 female headed households who are widowed from the 393 sampled producers of cereal and crops. The merchants those researchers get in the market are only male whereas other key respondents who are government employee work in related office are 2 females and 8 males. In salale farmer 
union the researcher interviewed one person who is also male. Totally, the study contacts with 424 peoples in both methods i.e. by direct interview and distributing questionnaires. The result shows us about $88.44 \%$ respondents are male, headed while the left $11.56 \%$ are female headed.

Land size and land use: Land is possibly the most significant factor of production and compute of wealth in the study area. Out of $89 \%$ cultivated land in the study area, $83 \%$ of land is covered by cereal and pulse crops. The remaining land represents land used for pastoral and forest land.

The survey results indicate that the cultivated landholding of cereal and pulse crops producing sample households ranged from 0 to 25 timad $^{1}$ with standard deviation of 4.73 timad. However, the key informant farmers indicated that fragmentation of land is causing social as well as economic problems in the Zone.

Access to markets and other services: Access to different services has important contribution in improving production and productivity and thereby increasing marketable surplus and ultimately increases the income as well as profitability of smallholder farmers. The most important services that are expected to promote production and marketing of cereal and pulse crops in the study area include proximity to markets, access to credit, access to extension service, and access to market information.

Proximity to markets: Regarding the distance taken to travel from home to the nearest market place where they sold their product, sample taken crops producing farmers reported that they travel an average of 0.2 and 12 hours respectively with corresponding standard deviations of 4.6 hours. ${ }^{2}$

Access to extension services: The higher access to the extension service, that farmers adopt new technology, information and awareness from another farmer or development agents. To maximize the knowledge and awareness the government addresses in many Kebele administration three development agents (DAs) and building a farmer training center. The kebele level development agents are the most actors as sources of extension services to transfer agricultural technologies and information to farmers. The effort to disseminate new agricultural technologies is influenced by the efficiency of communication between the development (change) agent and the farmers at grassroots level. Outof the total respondents $66.4 \%$ of the respondents have contact with government extension worker but $47.3 \%$ of total populations are profitable.

Farm Inputs utilization: Fertilizer application is one of the most important agricultural inputs that are used for teff, wheat, bean, millet and burley growers in the study area. Moreover, proper application of the recommended fertilizer rate is important to obtain the required production and marketable supply. Farmers in the study area use varying fertilizer rate, which is below the national level standard recommended rate. Although, all sample respondents applied DAP (Di Ammonium phosphate), UREA, NPS (Nitrogen phosphorus

${ }^{1}$ One timad is 0.25 hectare in the study area

2 Averagely 1kilometere takes 15 minute on foot 
sulfur) fertilizers and herbicides to produce cereal crops, insecticide for pulse production the rate of application is below the recommendation.

About $97.5 \%$ respondents applied different modern inputs to produce cereal and pulse crops. Sample farmers indicate different reasons for applying lower rate of fertilizer. The first reason is lack of financial capacity. This is followed by unavailability of fertilizer at the right time. According to their view, the amount of fertilizer to be applied per hectare of land depends on intensity of land preparation and fertility status of the plot. The result is assisting in revisiting the blanket recommendations for the entire zone. There is a need to conduct site-specific trails by the farmers themselves. Additionally, improved seed is also one of the most important inputs that determine productivity and production of cereal and pulse. However, the potential production response of improved seeds is determined by proper rate of fertilizer application.

Low pricing and cheating of traders during measuring: farmers in the study area are simply cheated in measurement scale during theysell their products in the market. The case is particularly intense at time of peak supply or harvesting season, when sample farmers sell in bulk. In the meantime, the price of traders offered to farmers is low, without actual interaction of supply and demand in the market. In addition to this, the cheating of traders in weighting the product forced farmers to sell by unfair weigh their products to some other place prior to marketing. This additional weighting of the product brings extra costs to farmers after harvest $26.46 \%$ of the farmers in the area are highly cheated by measurement material. Due to low awareness farmer cannot avoid such a problem of cheating in weighting.

Lack of market information: The presence of market information providing institution is important in decreasing the inefficiency and ineffectiveness of marketing activities. Provision of market information plays a decisive role in farmers' decision making process. This makes farmers to reduce risks and uncertainties associates with the market and makes them to take the right decision. In a few study areas, the display of the Ethiopian Commodity Exchange stands in street but its information access is out dated. However, the absence of this information providing institution in the study area makes farmers loose price during marketing.

Taxes Period: According to the report of sample respondents, tax is collected during harvesting time. Out of the total sample 393 respondents $68 \%$ of the farmer sale high quantity of crops during this period. This also leads farmer to unfair low price marketing. So some adjustment concern taxation is vital solution for this problem.

Higher price farm input: The increasing price of agricultural inputs in the Zone is not only problem of the production but it is also marketing problem of farmers faced while buying agricultural inputs in the market prior to production. Thus, 93\% of the total sample respondents report that they face higher input price during planting season.

Low bargaining power: The farmers have not any power to set price for both cereal and pulse crops. The farmers take any price set by merchant in the area. Only $3.3 \%$ of the farmer in the area are supply their product to farmers' cooperative and relatively high bargaining 
power.

\section{Cereal and Pulse Crops Market Channels}

The most important routes (channels) involve in the transfer in the study area cereal and pulse crops are listed below.

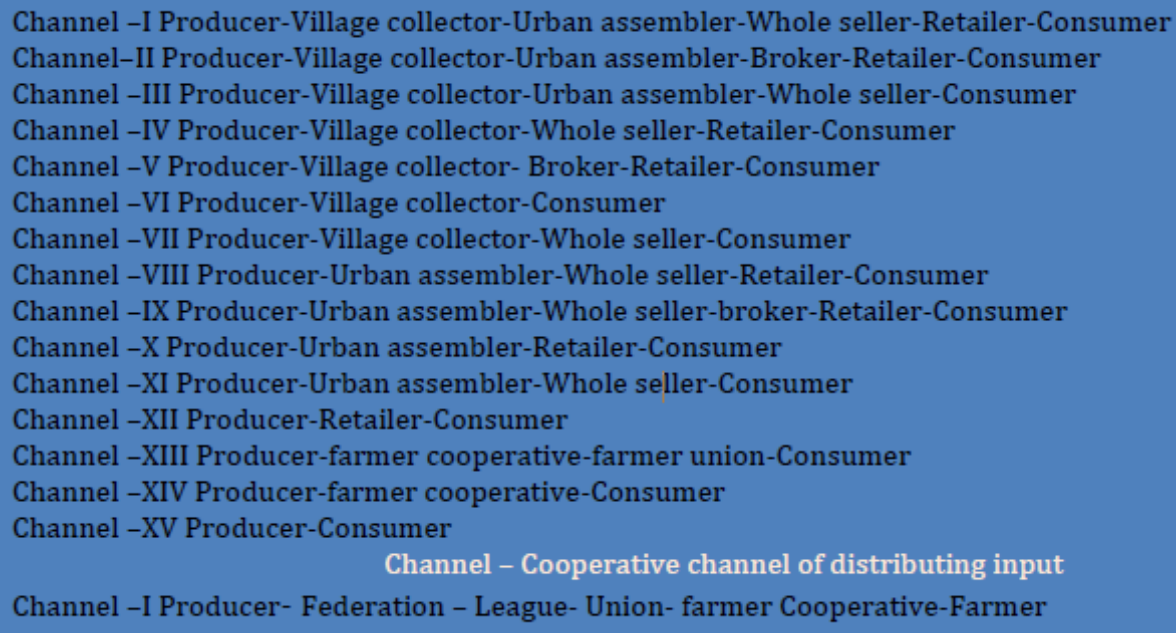

Figure 1. Marhet Channel Found in the Area

Source: Own survey, 2016.

From the above chain figure we can conclude that large market channel have many impact on both producer and consumers. Long channel decreases farmer income and increases consumers cost of food. The commodity should flows from producer to either final consumer, farmer cooperative or processors. And also the channel of the input market is long with many market actors. This is another problem of the farmer. Unnecessary market actors have been collapsed and direct marketing system is more favorable for the farmers.

\subsection{Empirical Data Analysis}

Post Diagonisis Test result: Cereal is produced for both consumption and sale in north Shewa Zone of Oromia Regional State. But, pulses are produced mainly for market purpose as cash crops in the area. According to the research report, many of sample households are good suppliers of the commodity to the market.

Test for multicollinearity: Mean VIF value is less than $5^{3}$. This indicates absence of serious multicollinearity problem among independent continuous variables. Contingency coefficient result is also less than $0.75^{4}$ that indicates absence of serious multicolliniarity problem among the independent dummy variables. Since there is heteroscedasticity ${ }^{5}$ problem in the data set, the parameter estimates of the coefficients of the independent variables cannot be constant variance. Therefore, to overcome these problems, robust Logistic regression analysis

\footnotetext{
${ }^{3}$ MEAN VIF $=1.80$

${ }^{4} \mathrm{CC}=0.63$

${ }^{5} \operatorname{chi} 2(15)=241.15($ Prob $>$ chi2 $=0.0000)$
} 
is used.

Nine explanatory variables are selected to determine the household profit of cereal and pulse crops. The variables are selected by top down selection strategy based on their coefficients and p-values. Among these variables, seven variables namely (Education, fixed cost, road access, number of oxen, Average price, Marketing problem and improved seeds) are found significant variables. While two variables (Fertilizer cost and awareness) are statistically insignificant they have no impact on dependent variable.

\subsection{Logistic Regression Model Interpretation}

The result of logistic model analysis indicates that, the coefficient of education is positive and statistically significant at $1 \%$. This result shows that household head with higher education level are more likely to be profitable relative to households whose head is at lower level of education. This is because of when the head of household education level is gone to postsecondary school, he/she come to more productive, more awareness of marketing and more profitable.

Similar to education, the coefficient cost of land is positive and it indicates that households with large investment are more likely to be profitable than households with limited farm land. This is probably because households with large farm land have high production and get relatively high profit. The cost of land is statistically significant at $5 \%$.

In contrast to education the coefficient of road access is negative and statistically significant at $1 \%$. It indicates that households who have less road access is less likely to be profitable than those who have more road access. That means, higher road distance by households from market implies that less opportunity to sell his/her product. They take low local price set by the village crops collectors.

The coefficient of total average price of product is positive and statistically significant at $1 \%$. It indicates that households who sell by high price are more likely to be profitable than those who sell by less price. This is because of price directly influence the profitability of the farmer.

The coefficient of improved seed cost is positive and statistically significant at $1 \%$. It indicates that households who use more improved seed are more likely to be profitable than those who use less improved seeds. That means, using more improved seed by households imply that high opportunity to get high production. This leads farmer to get high profitable from large quantity production.

In addition, the coefficient of number of oxen owned by household is positive and statistically significant at $5 \%$. It indicates that households who have more oxen are more likely to be profitable than those who have less oxen. That means, more oxen create opportunity to plough additional land by households. This implies that high opportunity to plough land imposing farmer to get high production. This reveals farmer gets high profit from large quantity production.

However, the coefficient of the marketing problem adversely relates to profitability of the 
farmer. It is statistically significant at $10 \%$. The result show that, farmers who have more market problem are less likely to profitable than that those who have less market problem. This is because of marketing problem creates high transaction cost and cheating for farmer house hold.

Table1. Logit and Marginal Effect for Profit Determinant

\begin{tabular}{|l|l|l|l|l|}
\hline \multicolumn{1}{|c|}{$\begin{array}{c}\text { Name of independent } \\
\text { variable }\end{array}$} & \multicolumn{1}{c|}{$\begin{array}{c}\text { Logistic } \\
\text { coefficient }\end{array}$} & \multicolumn{1}{c|}{$\begin{array}{c}\text { Marginal effect } \\
\text { dy/dx }\end{array}$} & $\mathrm{z}$ & $\mathrm{P}>/ \mathrm{z} /$ \\
\hline Education & .8626609 & .2036618 & 3.36 & $0.001 * * *$ \\
\hline Cost of land & .0005425 & .0001281 & 2.51 & $0.012^{* * *}$ \\
\hline Market info & -4.227857 & -.7051181 & -2.93 & $0.003 * * *$ \\
\hline Average price & .0016252 & .0003837 & 2.95 & $0.003 * * *$ \\
\hline Road access & -1.096483 & -.2588639 & -6.72 & $0.000^{* * *}$ \\
\hline Awareness & -.1934853 & -.0456791 & -0.45 & 0.651 \\
\hline Marketing problem & -.2163758 & -.0510832 & -1.76 & $0.079 *$ \\
\hline Fertilizer cost & -.1701511 & -.0401702 & -0.64 & 0.525 \\
\hline Improved seed & .0034248 & .0008086 & 5.94 & $0.000^{* * *}$ \\
\hline Number of oxen & .7167971 & .1692255 & 2.38 & $0.017 * *$ \\
\hline Pseudo ${ }^{2}$ & 0.6703 & & & \\
\hline Prob>chi ${ }^{2}$ & 0.0000 & & & \\
\hline Wald chi ${ }^{2}$ & 193.52 & & & \\
\hline Log pseudo likelihood & -88.771406 & & & \\
\hline No. of Observation & $389^{6}$ & & & \\
\hline
\end{tabular}

*** indicates $1 \%$ significant level, ** indicates $5 \%$ significant level and * indicates $10 \%$ significant level

Source: Own computation, 2016

Results of Marginal Effect Estimation from table 1

1. Average Price: The marginal effect result shows that average price of product is significantly affects profit of cereal and pulse crops at $1 \Upsilon \%$ level. The result also implies that, increase in price of cereal and pulse crops product by $1 \%$ causes an increase of farmers' profitability by $0.038 \%$ in average level ceteris paribus. Previous study by Muhammed (2011); who illustrated on price of teff and wheat production by farming households has augmented an increase marketable supply of the commodities significantly.

2. Education level of HHH: Education shows positive effect on profitability of farmer at $1 \%$ level. This is due to educational level of household head increases one level up then profit increases by 0.261 units at average level. The result further indicates that, education improves

\footnotetext{
${ }^{6}$ Number of observation described in sample size is 393 which are different from 389 . This is because of stata software omitted respondent with miss same data.
} 
the producing household ability to acquire new idea in relation to market information and improves production, which in turn enhances productivity and thereby increases profitability of cereal and pulse crops production. Study of Mekbib et al., (2014) illustrated if paddy producer gets educated, the amount of paddy supplied to the market increases, which suggests that education improves level of sales that affects the marketable surplus.

3. Cost of land: The other significant variable is cost of land at $5 \%$ level, which affects positively the profitability of farmer. When the additional land cost is increase by $1 \%$ the profitability of the farmer who produce cereal and crop is increase by $0.013 \%$ at average level. Getachew et al., (2014), who study on pepper market analysis, found that cost of land positively affects the quantity supply of the producer.

4. Improved seed: The marginal effect shows improved seed has positive and statistically significant effect at $1 \%$. The study shows only a few farmer uses improved seed are profitable. The amount of improved seeds uses by farmer increases by $1 \%$ averagely reveals the increasing profit of the household by $0.08 \%$ unit. This is because of using improved seeds increase the productivity of the farmer that has direct relation with profit of farmer. Ayelech, 2011, who illustrated an increase of mango; avocado and papaya production by farmer household, has augmented marketable supply of the commodities significantly.

5. Road access: Having good road access positively affects the profitability of rural household. Poor road acces negatively affect the profit, that is when distance of house hold increase by one hour walk on foot ${ }^{7}$ the profit of house hold decrease by 0.2588 at average level. This is in line with the World Bank (2004) report that better road density in the study area i.e. $117 \mathrm{~km}$ per 1000 square $\mathrm{km}$ which is by far better than the national road infrastructure i.e. $30 \mathrm{~km}$ per 1000 square $\mathrm{km}$ with significant difference between the three locations at one percent level of significance.

6. Oxen: Oxen are the major factors of productivity in the study area. Its effect is positive and statistically significant at 5\%. Oxen uses for land plough and collecting harvested crops in the area. When the number of ox increases by one at average the profit increases by 0.186 units keeping other things constant.

7. Marketing problem: Marketing problem expects to adversely affect the profit of farmer household. Marginal effect results show, this variable is negatively related profit of the farmer and statistically significant at $10 \%$. The result implies that farmers who have any types of marketing problem increase by one unit decreases profit of the farmer by 0.051 unit at average level. This is because of any cheating or distance of the market decrease the price of the cereal and pulse crops. Decrease of the price reveals by decrease of the profit of the farmer.

\section{Conclusion}

There is a complex relationship between profitability of the rural agriculture and welfare of rural farming households. Though widely accepted as agricultural technology and market

\footnotetext{
7 Averagely peoples go 4.5 kilometers per hour.
} 
system has enhances welfare, assessing the impact of agricultural technology adoption at profitability of farmer at household level is challenging due to the difficulties in net out the impact of different economic habit of farmer. A counterfactual outcome framework of modern evaluation theory is used to measure the effect on the outcome indicator. Hence, this study tried to assess the contribution of market chain and transaction cost on farmers profitability using logistic regression model. In addition the Breuch pagans (Cook Weighting test for heteroscedasticity, CC and VIF for multicollinearity test is used in the study. The study employs cross sectional data in 2014/2015 cropping season from 393 sample farming households and 31 key informant interviewed respondent.

Absence of organized institution and system group marketing has made traders in a better position to dominate the roost in pricing. The research result also indicates the existence of fifteen types of market chain in crops sell. The longest holds five chain and the shortest takes from producers-Consumer channel. The producers-Consumer channel is important for producers and consumers to get acceptable prices; while Producers-Local collector-Wholesaler-Terminal market channel and Producer-Wholesaler-Retailer-Consumer channel are the most important channels in terms of total volume marketed for cereal and pulse crops. Besides, the input supply has also six channels that increase service cost in all channels.

Educational level has vital role to use as tool to solve the general problems concerning new technology and marketing system of the farmer household. Additionally, having good road access and financial institution are also the clue to solve farmer constraint and made farmers more profitable.

Even if farmer cooperative is established in all kebeles, farmers do not serve well from the cooperative in the area. Lack of knowledge among the farmers, less access of road, unstandardized measurement material and less market information are the problem of the farmers. The result of the study generally confirms the well organizes market and marketing through farmer cooperative leads farmer to welfare improvement of farming communities.

Based on the above findings, the following policy recommendations are made.

- Since there is a large potential benefit, market chain in enhancing the profitability of rural farming communities, efforts should be geared towards this market system through creating sufficient awareness about farmer cooperative, disseminating road access to all kebeles and creating better access to market chain relates facilities for the farming households.

- Access to education and information serves the farmer to get the ability to perceive, interpret and make informed decisions about the new technologies and marketing system. Thus, committed efforts towards the adoption of improved agricultural technologies can possibly realized the green revolution in developing countries like Ethiopia which ultimately enhances the welfare of poor rural farming communities.

- The long chain of agricultural market input increases transaction cost government has to look again and decrease unnecessary actor. 
- To minimizing the marketing problem, the concerned local government institution, and nongovernmental organization should work with farmer and scale up the knowledge of farmers by training.

- Ethiopian Commodity Exchange should be widespread information displayer board in all woredas and should take information by displaying daily price to the farmer.

- Local government (trade and market development office) should monitor and manage measurement material and made regulation for block cheater merchant.

\section{Areas for Future Research}

This study is a cross sectional study which is a one-time snapshot and did not enable us to see the dynamics of the impact of the market chain. Hence, studies using panel data of farming households is recommended to show the dynamics of the impact estimate overtime. Increase in profit came with increase in income and saving. So the father impact of market chain to investment of farmer and capital accumulation is also open to farther researcher. In addition, studying the impact by including more variables indicators is encouraged to see on which outcome indicators the program works well and thereby inform stakeholders to work on accordingly.

\section{References}

Abreham, T. (2013). Value chain analysis of vegetables: the case of habro and kombolchaworedas in Oromia region, Ethiopia, Haromaya, Ethiopia.

Adugna, G. (2009). Analysis of Fruit and Vegetable Market Chains in Alamata, Southern Zone of Tigray: The Case of Onion, Tomato and Papaya.

Aklilu, Y. (2007). An assessment of supply and demand issues for the Ethiopian meat export industry. Un published manuscript.

Alemu, D. (2010). Seed system potential in Ethiopia Constraints and opportunities for enhancing the seed sector, IFPRI, Addis Ababa, Washington.

Awol, Z. (2010). Analysis of Poultry market Chain : the case of Dale and AlabaWoredas of Southern Nation Nationality and people, Ethiopia

Ayelech, T. (2011). Market chain analysis of fruits for GommaWoreda Jima Zone Oromia regional state

Bellu, G. (2013). Value Chain Analysis for Policy Making Methodological Guidelines and country cases for a Quantitative Approach VialedelleTerme di Caracalla, Rome, Italy.

Christy. (2009). Enabling Environments for Competitive Agro-industries, in da Silva $2^{\text {nd }}$ eds., Agro-industries for Development, FAO and UNIDO, Rome, Italy.

Creswell, J. W., (2009). Research Design: Qualitative, Quantitative, and Mixed Methods Approaches, 3rd edition, Landon, Sega publications.

CSA. (2008). Area and production of crops (private peasant holdings, meher season) 
Agricultural Sample Survey 2007 / 2008 Volume I Addis Abeba Ethiopia.

CSA. (2012). Agricultural sample survey report on area and production of crops (private peasant holdings, meher season).Volume I. CSA, Addis Ababa, Ethiopia.

Dawson, C. (2009). Introduction to research methods: A practical guide for any one undertaking a research project, 4th edition, United Kingdom, Books Ltd.

Dzanjala, J, Kepondamgaga, P., \& Tchaleh (2013). Value chain analysis of beef in central and southern Malawi case study of Lilongwe and chikhwanh district Lilongwe University of Agriculture and Natural Resources, Malawi,

FAO (Food and Agriculture Organization). (2006) Value Chain Analysis: A Case Study on Mangoes in Kenya, Prepared By the Sugar and Beverages Groups Raw Materials. Tropical and Horticultural Products Service Commodities and Trade Divisions Food and Agriculture Organization of the United States.

Gebremariam, G. Gebremedhin \& Yemiru, T. (2015). Market chain analysis of live goats Asaita District, Afar Regional State, Ethiopia, International Institute for Environment and Development 80-86 Gray's Inn Road, London WC1X 8NH, UK

Getachew, L., Mohammed, H., Retta, G., \& Tibebu, K. (2014). Value Chain Assessment of Selected Vegetable Products in Central Rift Valley of Ethiopia.

Greene, W. (2012). EconometricsAnalysis Dorling Kindersley Plc. New Delhi, India.

Guidi, D. (2011). Sustainable agriculture enterprise farming stratagem to support small holder inclusive value chains for rural poverty alleviation, Center for International Development at Harvard University Harvard, USA.

Gujarati, D. (2009). Basic Econometrics $5^{\text {th }}$ edition Tata McGraw Hill Education Plc. New Delhi, India.

Hobbs, J., Cooney, A., \& Fulton, M. (2000). Value market chains in the agri-food sector: What are they? How do they work? Are they for me?, University of Saskatchewan, Canada.

ILO (International Labor Organization). (2009). Enterprise Development through Value Chains and Business Service Markets: A Market Development Approach to Pro Poor Growth" Geneva, New York.

Janet, M., \& Ruane (2006) Essentials of Research Methods. A Guide to Social Science Research. USA, Blackwell Publishing.

Kirsten, J., Dorward, A., Poulton, C., \& Vink, N. (2009) Institutional Economics Perspectives on African Agricultural Development Library of Congress Cataloging-in-Publication Data Washington, D.C., U.S.A.

Lundy, M., Gottret M. V., Cifuentes, W., Ostertag, C. F., Best, R., Peters, D., \& Ferris, S. (2004). Increasing the Competitiveness of Market Chains for Small-holder Producers. Manual: Territorial Approach to Rural agro-enterprise Development. International Centre for 
Tropical Agriculture. Colombia, USA.

Malik, D., Sigh, S. N., \& Rai, K. N. (1993). Marketed and Marketable Surplus of Wheat and Paddy Crops in Kuruk Sheta District of Harchyana, India. Journal of Agricultural Marketing, New Delhi India

Mankiw, N. G. (1998). Macroeconomics $5^{\text {th }}$ edition Library of Congress Washington DC., USA

Mekbib, H., \& Matthias, K. (2006). Price expectation formation of smallholder farmers in Ethiopia: What explains their forecasting efficiency?" Center for development Research, Bonn University, Bonn, Germany.

MOARD. (2010). Crop Variety Registration. Crop Development Department, Addis Ababa, Ethiopia.

MoFED (Ministry of Finance and Economic Development). (2011). Ethiopia's Progress towards Eradicating Poverty: An Interim Report on Poverty Analysis Study (2010/2011). Addis Ababa, Ethiopia: Ministry of Finance and Economic Development, Federal Democratic Republic of Ethiopia.

Mohammed, A., \& Muhammed, S. (2015). Assessment of marketing practices and challenges of Mung bean (Masho) in Amhara regional state: experience from north shewa zone, UnpublishedResearch D/Birhan, Ethiopia

Mohammed, H. (2011). Report on training on value chain development, Meki, Ethiopia.

Muhammed, U. (2011). Market chain analysis of teff and wheat production in Halaba Special Wereda of Southern Ethiopia.

Nigussie, T., Mulat, D., Shahidur, R., \& Francois, K. (2014). A Dynamic Analysis of Food Demand Pattern and Habit Effects: Panel Evidence from Rural Households in Ethiopia.

Sintayehu, G., Samuel, A., Derek, B., Ayele, S., \& Ryan, D. (2013). Study of the Ethiopian live cattle and beef value chain, International Livestock Research Institute (ILRI)

Tilahun, G., Tesfaye, L., Dirk, H., Azage, T., \& Bogale, A. (2012). Participatory smallholder dairy value chain development in Fogera woreda, Ethiopia: Experiences from IPMS project interventions International Livestock Research Institute (ILRI), Addis Ababa, Ethiopia.

UN (UNITED NATION). (2010). Integrating Developing Countries' SMEs into Global Value Chains, New york, Geneva

USAID (United States Agency for International Development). (2005). Global horticultural assessment, USA.

Varian, H. (1992). Microeconomics Analysis $3^{\text {rd }}$ Edition Library of Congress Cataloging-in-Publication Washington Dc, USA.

Webber, M., \& lambaste, P. (2010). Building Competitiveness in African Agriculture A guide to Value Chain Concepts and Applications" World bank Library of congress cataloging 
Washington DC, USA

WB (World Bank). (2004). Poverty Reduction and Economic Management, Country Department for Ethiopia: Opportunities and Challenges for Developing High-value Agricultural exports in Ethiopia, Africa region, background report, Washington, USA

WTO (World Trade Organization). (2011). Global Forum on Trade Statistics Measuring Global Trade - Do we have the right numbers?" Geneva, Switzerland.

Zekarias, Sh., Kaba, U., \& Zerihun, K. (2012). Analysis of Market Chains of Forest Coffee in Southwest Ethiopia, Academic Journal of Plant Sciences.

ZFED (Zonal Finance and Economic Development Office, 2014). Socio Profile of the North Shewa Zone, Fitche, Ethiopia.

\section{Copyright Disclaimer}

Copyright for this article is retained by the author(s), with first publication rights granted to the journal.

This is an open-access article distributed under the terms and conditions of the Creative Commons Attribution license (http://creativecommons.org/licenses/by/3.0/). 